\title{
The Niemcza diorites and monzodiorites (Sudetes, SW Poland): a record of changing geotectonic setting at ca. $340 \mathrm{Ma}$
}

\author{
Anna PIETRANIK ${ }^{1, *}$, Craig STOREY ${ }^{2}$ and Jakub KIERCZAK ${ }^{1}$ \\ 1 Institute of Geological Sciences, University of Wrocław, M. Borna 9, 50-204 Wrocław, Poland \\ 2 School of Earth and Environmental Sciences, University of Portsmouth, Portsmouth PO1 3QL, United Kingdom
}

Pietranik A., Storey C. and Kierczak J. (2013) The Niemcza diorites and moznodiorites (Sudetes, SW Poland): a record of changing geotectonic setting at ca. 340 Ma. Geological Quarterly, 57 (2): 325-334, doi: 10.7306/gq.1084

\begin{abstract}
Granites sensu lato in the Sudetes intruded in several episodes during the Variscan orogeny recording different stages of crust and mantle evolution. Correlating precise ages with geochemistry of the Variscan granites provides information on the evolution of these sources within the Variscan orogen. The Variscan intrusive rocks from the Niemcza Zone (Bohemian Massif, Sudetes, SW Poland) include undeformed dioritic to syenitic rocks and magmatically foliated granodiorites. In this study we analysed low $\mathrm{SiO}_{2}$ (48-53 wt.\%) monzodioritic rocks from Przedborowa and Koźmice. The monzodiorites contain late-magmatic zircons with ages of 341.8 \pm 1.9 Ma for Przedborowa and 335.6 \pm 2.3 Ma for Koźmice, interpreted as emplacement ages of the dioritic magmas. Older Przedborowa rocks are lower in $\mathrm{K}, \mathrm{Mg}, \mathrm{Rb}$ and Ni than the Koźmice rocks and similar compositional trend is also observed in the Central Bohemian Plutonic Complex. The implication is that the mantle underlying the Niemcza Zone became more enriched from ca. 342 to ca. $336 \mathrm{Ma}$, probably following the collision of the Saxothuringian and Moldanubian/Lugian domains. The magmatism related to the collision occurred ca. $12 \mathrm{Ma}$ later than that in the Central Bohemian Plutonic Complex, but was accompanied by a similar change in magma chemistry from high-K (Przedborowa) to shoshonitic (Koźmice, Kośmin enclaves) and probably to ultrapotassic (Wilków Wielki).
\end{abstract}

Key words: Bohemian Massif, Niemcza Zone, diorites, LA-ICPMS zircon age, potassic magmatism.

\section{INTRODUCTION}

Variscan granitoid magmatism in the Sudetes spans from ca. 350 to ca. $295 \mathrm{Ma}$ (Mazur et al., 2007 and references therein). Recent zircon dating provides precise ages and shows that the magmatism in the Sudetes occurred in three major episodes:

- ca. 340 Ma episode, which includes emplacement of granodioritic and monzonitic magmas in the Odra Fault Zone (344 $\pm 1 \mathrm{Ma}$; Dörr et al., 2006), granodioritic and dioritic rocks in the Niemcza Zone (336 \pm 3 Ma to $342 \pm$ 2 Ma; Oliver et al., 1993) and leucocratic granite bodies within the Gogołów-Jordanów serpentinite massif (337 \pm $4 \mathrm{Ma}$; Kryza, 2011);

- ca. $320 \mathrm{Ma}$ episode, which includes the Karkonosze Granite (322 \pm 3 Ma; Kryza et al., 2012) and the Bożnowice tonalite from the Strzelin Massif (324 $\pm 4 \mathrm{Ma}$; Oberc-Dziedzic et al., 2010);

- ca. 300 Ma episode, which includes granitic to tonalitic rocks in the Strzelin Massif (306 \pm 3 Ma to $294 \pm 3 \mathrm{Ma}$; Oberc-Dziedzic et al., 2010; Oberc-Dziedzic and Kryza, 2012) and the Strzegom-Sobótka granites (294-310 Ma; Turniak et al., 2005).

* Corresponding author: anna.pietranik@ing.uni.wroc.pl Received: January 28, 2013; accepted: March 21, 2013; first published online: April 15, 2013
Precise dating and recognition of magmatic episodes is important for larger scale correlations of changing tectonic settings during the Variscan orogeny. For example, ca. $340 \mathrm{Ma}$ magmatism is widespread in the Bohemian Massif and is represented by ultrapotassic rocks ( $340 \pm 8 \mathrm{Ma}$ to $343 \pm 6 \mathrm{Ma}-$ Holub, 1997; $337 \pm 1 \mathrm{Ma}-$ Janoušek and Gerdes, 2003; $342 \pm$ $3 \mathrm{Ma}$ - Kusiak et al., 2010; $335.12 \pm 0.57 \mathrm{Ma}$ - Kotková et al., 2010), which include numerous bodies of high-Mg, high-K melasyenites to melagranites (Wenzel et al., 1997). The main scenario for high-K, high-Mg magmatism involves interaction between crustal and enriched mantle sources coupled with fractional crystallisation (Janoušek and Holub, 2007; Parat et al., 2010). Pinpointing the crustal source involved in the ultrapotassic rocks' geneses strongly depends on precise and accurate dating of the magmatism (Janoušek and Holub, 2007; Kotková et al., 2010).

Leichmann and Gawęda (2002) suggested that the Niemcza Zone intrusives can be correlated with the ultrapotassic rocks from other localities in the Bohemian Massif and by implication they could have been formed in a similar geotectonic setting. However, ages of the Niemcza Zone dioritic rocks and their detailed geochemical characteristics have been so far insufficient to verify this hypothesis. Previous dating of the Koźmice granodiorite by ID-TIMS (isotope dilution - thermal ionization mass spectrometry) of zircon yielded a Concordia age of $338+2 /-3 \mathrm{Ma}$ (Oliver et al., 1993) similar to that of other ultrapotassic rocks (e.g., Holub, 1997; Janoušek and Gerdes, 2003; Kotková et al., 2010; Kusiak et al., 2010). Pegmatitic amphiboles from Przedborowa yielded a similar age of $335 \pm 5 \mathrm{Ma}$ 
by the ${ }^{40} \mathrm{Ar} /{ }^{39} \mathrm{Ar}$ method (Dudek et al., 2000). In this paper, we present the first ages for zircons from monzodioritic rocks from Koźmice and Przedborowa. We compare the geochemical composition of the rocks with others of similar age in the Bohemian Massif in order to see if similar sources were present at a regional scale during the Variscan orogeny.

\section{GEOLOGICAL SETTING}

The Niemcza Zone is located in the Bohemian Massif (Fig. $1 \mathrm{~A}$ ), in the Sudetes at the eastern margin of the Góry Sowie Gneissic Block, and forms a N-S elongated shear zone (Fig. 1B) predominately composed of mylonitised gneisses of the Góry Sowie Massif (Mazur and Puziewicz, 1995; Fig. 2). The Niemcza Zone also comprises small bodies of mafic-ultramafic rocks belonging to the Central Sudetic Ophiolite formed at ca. $400 \mathrm{Ma}$ (U-Pb zircon SHRIMP age; Kryza and Pin, 2010) and small intrusions of granodioritic and dioritic rocks formed at ca. 338 Ma (U-Pb zircon ID-TIMS age; Oliver et al., 1993; Fig. 2). The ca. $338 \mathrm{Ma}$ intrusive rocks can be divided into two groups: dioritic rocks, called the Przedborowa type and granitic rocks called the Kośmin type (Dziedzicowa, 1963).

The dioritic rocks (Przedborowa type) form fine-grained dikes comprising monzodiorites, quartz diorites, quartz syenites and tonalites. They are composed predominately of plagioclase, amphibole and biotite with minor clinopyroxene and K-feldspar (Dziedzicowa, 1963; Puziewicz, 1987, 1988, 1990). The initial ${ }^{87} \mathrm{Sr}^{86} \mathrm{Sr}_{\mathrm{at} 338}$ is 0.70598 for diorites from Przed- borowa (Lorenc, 1998; Lorenc and Kennan, 2007, ${ }^{87} \mathrm{Sr} /{ }^{86} \mathrm{Sr}_{\mathrm{at3} 38}$, recalculated using ${ }^{87} \mathrm{Rb}$ decay constant of Nebel et al., 2011).

The granitic rocks (Kośmin type) locally show effects of ductile dextral shearing (Puziewicz et al., 1992, Aleksandrowski et al., 1997) interpreted as magmatic deformation (Puziewicz, 1992). The rocks are medium-grained, rich in dioritic enclaves and comprise granodiorites, quartz monzonites, quartz monzodiorites and rare granites. They are composed of various proportions of quartz, feldspars, biotite and amphibole (Puziewicz, 1992; Puziewicz and Oberc-Dziedzic, 1995; Lorenc, 1998; Lorenc and Kennan, 2007). A petrological study of the Koźmice granodiorite gave estimates of magma crystallization temperature of $730-850^{\circ} \mathrm{C}$ and the pressure of emplacement at $4 \pm$ 1 kbars (Puziewicz and Radkowska, 1990; Puziewicz, 1992). The initial ${ }^{87} \mathrm{Sr}^{86} \mathrm{Sr}_{\mathrm{at} 338}$ is $0.7077-0.7079$ for the granodiorites in Kośmin (Lorenc,1998; Lorenc and Kennan, 2007).

The granitic rocks were emplaced contemporaneously or later than the dioritic rocks (Puziewicz, 1992). The dioritic rocks are undeformed and the granitic rocks are weakly foliated and are characterized by $\mathrm{N}-\mathrm{S}$ and $\mathrm{E}-\mathrm{W}$ trending foliation and dextral shearing (Puziewicz, 1992). Lack of deformation in the dioritic rocks as well as different shear sense recorded in the granitic rocks compared to that in the surrounding mylonites (dextral versus sinistral) indicate that the intrusive rocks were younger than the pervasive deformation in mylonites (Mazur and Puziewicz, 1995). Alternatively, the intrusive rocks may have survived unaffected by the later sinistral shearing (Aleksandrowski et al., 1997).

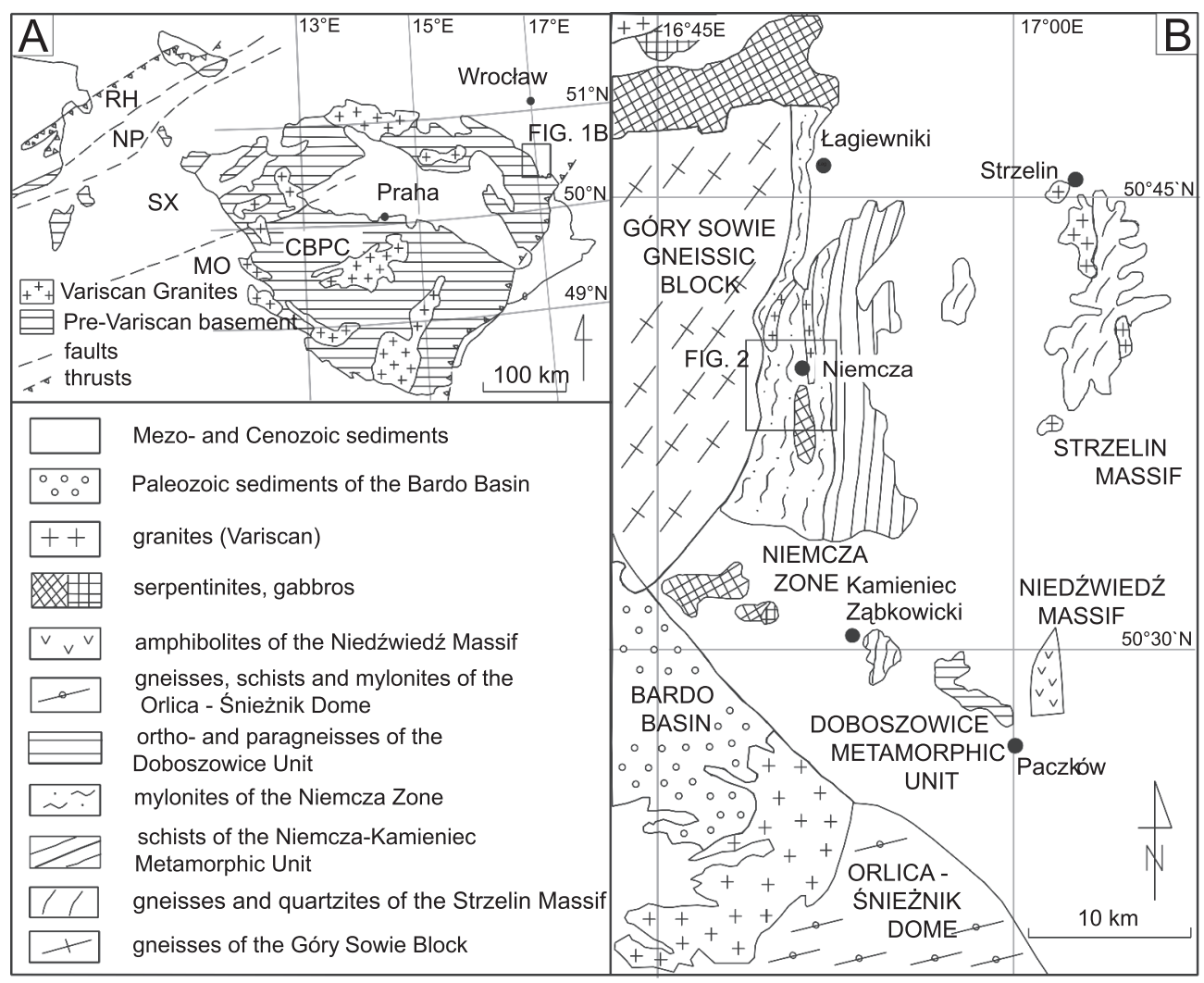

Fig. 1. Generalised map of (A) the Bohemian Massif and (B) the Eastern Sudetes showing the location of the Niemcza Zone and the studied area (small square in Fig. 1B see Fig. 2)

A - CBPC - Central Bohemian Plutonic Complex, MO - Moldanubian Zone, NP - Northern Phyllite Zone, RH - Rhenohercynian Zone, SX - Saxothuringian Zone 


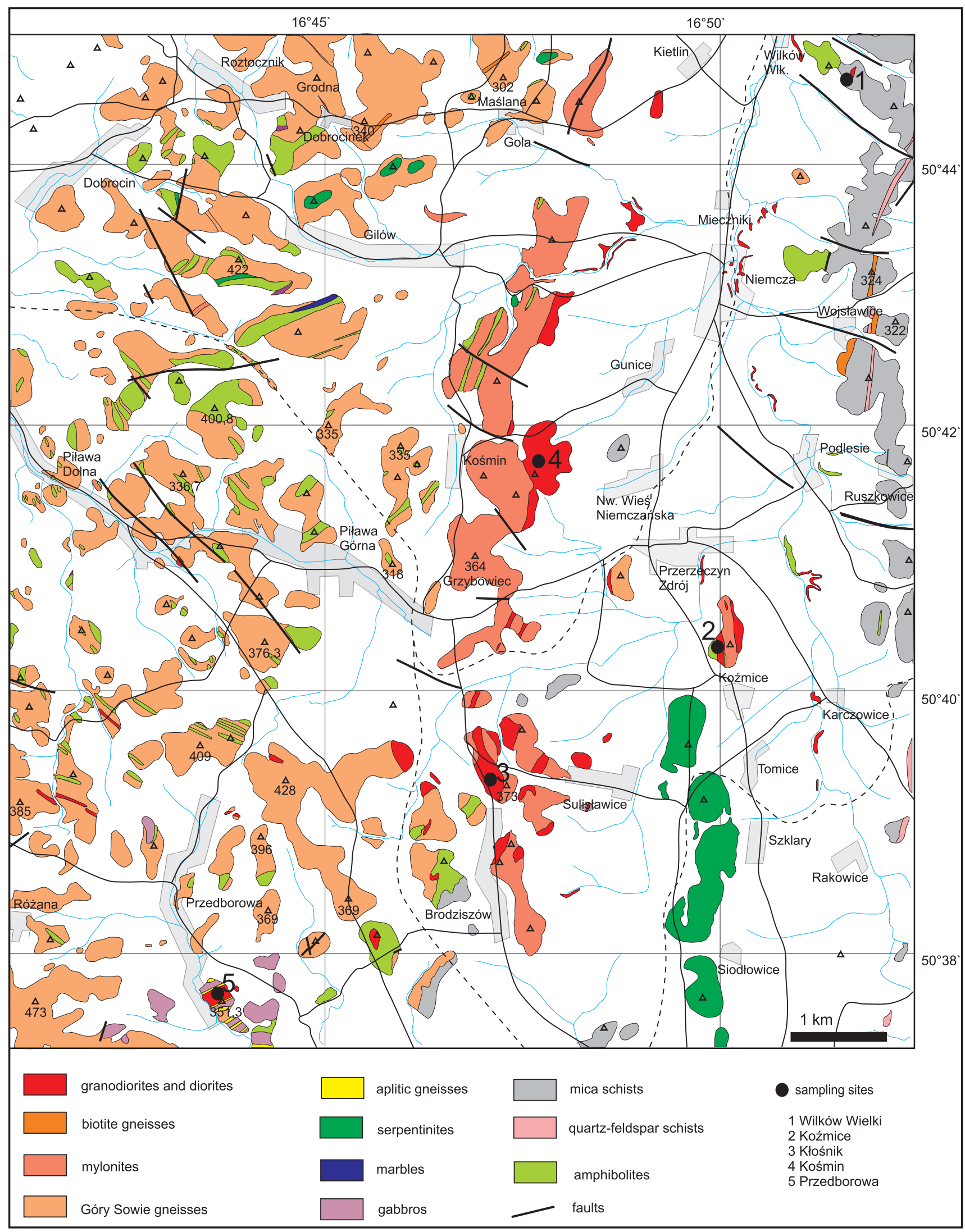

Fig. 2. Geological map showing sampling sites of the dioritic/syenitic rocks analysed in this study (modified after Trepka and Gawroński, 1957; Badura and Dziemiańczuk, 1981; Cwojdziński and Walczak-Augustyniak, 1983; Cymerman and Walczak-Augustyniak, 1986) 


\section{ANALYTICAL METHODS}

\section{ZIRCON DATING}

Approximately $3 \mathrm{~kg}$ of fine grained, dioritic rocks from the Przedborowa and Koźmice quarries were crushed and sieved. Heavy mineral concentrates were separated from the sieved fractions by panning and zircons were handpicked and mounted in an epoxy ring. The grains were examined in charge contrast images. U-Pb analyses of zircon were carried out at the University of Bristol using a Thermo-Scientific Element single-collector ICP-MS (Inductively Coupled Plasma - Mass Spectrometry) coupled to a New Wave 193HE laser ablation sampling system. The single measurement comprised: $20 \mathrm{~s}$ of gas blank measurement, $40 \mathrm{~s}$ of zircon measurement and 1 minute of washing out. Data were corrected for $\mathrm{U}-\mathrm{Pb}$ fractionation and instrumental mass bias by standard bracketing with repeated measurements of the Plešovice zircon with an accepted ${ }^{206} \mathrm{~Pb} /{ }^{238} \mathrm{U}$ age of $337.13 \pm 0.37 \mathrm{Ma}$ (Sláma et al., 2008). During the session 15 analyses of the Plešovice zircon yielded a ${ }^{206} \mathrm{~Pb} /{ }^{238} \mathrm{U}$ concordia age of $338.1 \pm 1.1$ Ma showing good within-run reproducibility. Data reduction was carried out with the software package GLITTER® (GEMOC - The ARC National Key Centre for Geochemical Evolution and Metallogeny of Continents). The plotting and concordia age calculation was done by Isoplot (Ludwig, 1999), all errors are plotted and all ages are quoted at the $2 \sigma$ uncertainty level.

No ${ }^{204} \mathrm{~Pb}$ correction was applied to the data. ${ }^{204} \mathrm{~Pb}$ was measured during the session together with ${ }^{204} \mathrm{Hg}$ and $\mathrm{Hg}$ correction was applied to ${ }^{204} \mathrm{~Pb}$ resulting in values below detection limit for ${ }^{204} \mathrm{~Pb}$. The reference zircon 91500 with an accepted age ${ }^{206} \mathrm{~Pb} /{ }^{238} \mathrm{U}$ of $1062.4 \pm 0.8$ (Wiedenbeck et al., 1995) was analysed as unknown to check for data quality. The ${ }^{206} \mathrm{~Pb} /{ }^{238} \mathrm{U}$ age for the 91500 zircon measured in this study is $1065 \pm 4.6 \mathrm{Ma}(\mathrm{n}=$ 14 , MSWD = 0.8), in agreement with the age published by Wiedenbeck et al. (1995). Also, at the same session, zircons from the Gęsiniec tonalite were analysed and yielded a Concordia age of $294.7 \pm 1.5 \mathrm{Ma}(\mathrm{n}=10$, MSWD $=0.7)$, which is identical to the SHRIMP age of $294.7 \pm 2.8$ Ma obtained recently for the tonalite (Oberc-Dziedzic and Kryza, 2012). Correct values for 91 500, Gęsiniec zircon as well as Concordia ages for analysed zircons from the Niemcza Zone suggest that no ${ }^{204} \mathrm{~Pb}$ correction was required along with the fact that ${ }^{204} \mathrm{~Pb}$ could not be detected.

\section{CHEMICAL ANALYSES}

Whole rock geochemical analyses for ten samples were done in the ACME Analytical Laboratory (4 from Przedborowa, 2 from Koźmice and 4 of enclaves from Kośmin). Major elements were analysed by ICP-ES (Inductively Coupled Plasma Emission Spectrometry) and trace elements were analysed by ICP-MS following fusion of samples in $\mathrm{LiBO}_{2} / \mathrm{Li}_{2} \mathrm{~B}_{4} \mathrm{O}_{7}$. The analytical reproducibility (2SD), as estimated from 10 analysis of standard SO18/CSC is below $0.8 \%$ for major elements, and from $0.8(\mathrm{Nd})$ to $8 \%(\mathrm{La})$ for trace elements at $95 \%$ confidence limits. Analytical accuracy (2SD), as estimated from the real concentration in the standard SO18/CSC is below $4 \%$ for major elements and from $4(U)$ to $26 \%(Y)$ for trace elements at $95 \%$ confidence limits.

An additional 6 samples were analysed for major elements at the laboratory of the Institute of Geological Sciences, University of Wrockaw, Poland by a combination of AAS (Atomic Absorption Spectroscopy) and titration.

\section{RESULTS}

MONZODIORITE FROM KOŹMICE: PETROLOGY AND GEOCHEMICAL COMPOSITION

The monzodiorite from Koźmice crops out in the quarry on Strach Hill. The monzodiorite is in a sharp intrusive contact with granodiorite, the latter was dated by Olivier et al. (1993) at 338 $+2 /-3 \mathrm{Ma}$. Recrystallisation of monzodiorite at the contact with granodiorite indicates that the granodiorite magma intruded into already crystallised, older monzodiorite (Puziewicz, 1992). The petrology of monzodiorite was described in detail by Puziewicz (1988, 1992) and it is summarized here. The monzodiorite (called also vaugnerite) is fine-grained, undeformed and is composed of plagioclase, biotite and pyroxene. Zircon occurs within biotite, often at its rims (Fig. 3A). Pyroxene is replaced by amphibole close to the contact with granodiorite. Three samples of the monzodiorite were analysed in this study (two within approximately $20 \mathrm{~cm}$ of the contact and one a few metres from the contact with granodiorite). Zircons were separated from the sample collected farther away from the contact. This sample contains less $\mathrm{Si}, \mathrm{Cr}$ and $\mathrm{Ni}$ and slightly less $\mathrm{K}$ and $\mathrm{Mg}$ than the samples collected near the contact, other elements concentrations are similar (Appendix 1*). The dated sample has $52 \mathrm{wt} \% \mathrm{SiO}_{2}$ and moderate amounts of $\mathrm{K}_{2} \mathrm{O}(\sim 3 \mathrm{wt} . \%)$. It is also characterized by low Ni (8 ppm) and moderate Rb (150 ppm).

\section{MONZODIORITE FROM PRZEDBOROWA: PETROLOGY AND GEOCHEMICAL COMPOSITION}

Petrology of the quartz monzodiorite, the dominating rock in the Przedborowa Quarry, was described in detail by Dziedzicowa (1963) and Puziewicz (1990) and is summarised here. The monzodiorite forms an approximately $100 \mathrm{~m}$ thick, undeformed dike within amphibolites. The rock is fine-grained and composed predominately of plagioclase, amphibole (hornblende), biotite and alkali feldspar with minor quartz. Two dominating types of the monzodiorite include: equigranular monzodiorite and porphyritic monzodiorite (with biotite phenocrysts). Two samples of each type were analysed in this study for major and trace elements and two samples of the equigranular type were analysed for major elements only (Appendix $\left.1^{*}\right)$. Zircons were separated from the equigranular type. Zircon occurs within hornbende and biotite, usually close to their rims (Fig. 3B). The porphyritic type contains more $\mathrm{Si}$ and $\mathrm{K}$ and less $\mathrm{Fe}, \mathrm{Mg}, \mathrm{Ca}, \mathrm{Ti}$ than the equigranular type (Appendix 1). It is also richer in incompatible elements, such as $\mathrm{Rb}, \mathrm{Cs}, \mathrm{Ba}, \mathrm{Hf}, \mathrm{U}, \mathrm{Zr}$, but not LREE. The low- $\mathrm{SiO}_{2}$ samples (51-52 wt.\%) have moderate amounts of $\mathrm{K}_{2} \mathrm{O}(2-3 \mathrm{wt} . \%)$. They are also characterized by low $\mathrm{Ni}(6-9 \mathrm{ppm})$ and $\mathrm{Rb}$ concentrations (50-80 ppm). 

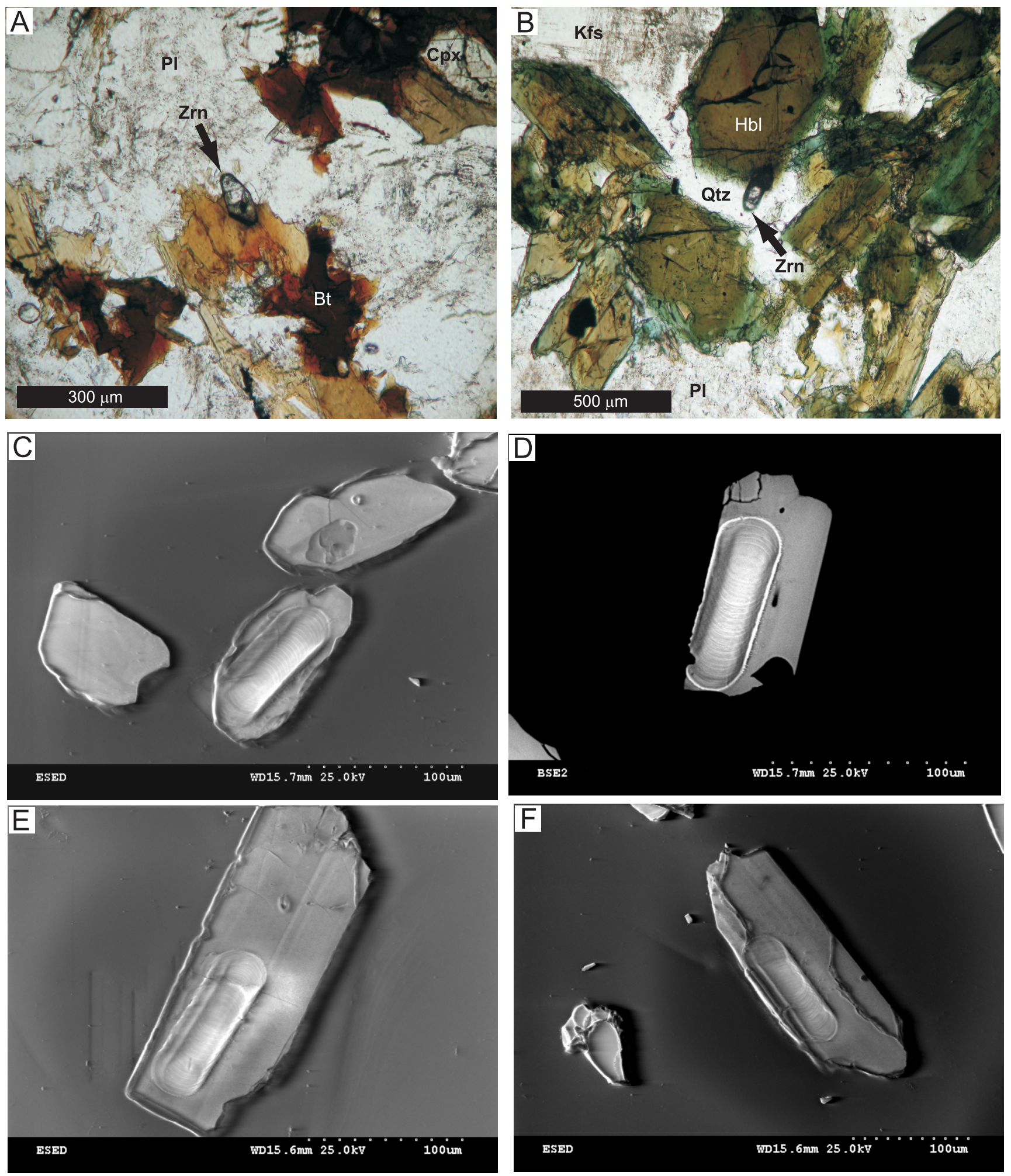

Fig. 3A, B - microscope view of Koźmice and Przedborowa monzodiorite dated in this study (plane polarized light), typical occurrence of zircon grains is marked by arrows; $C-F$ - charge contrast images of zircons; the linear pits represent the material ablated for dating; C, D - Koźmice; E, F - Przedborowa 


\section{MONZODIORITIC ENCLAVES FROM THE KOŚMIN QUARRY AND OTHER ROCKS}

Four monzodioritic enclaves were collected from the Kośmin Quarry in order to compare their geochemistry to that of Przedborowa and Koźmice. The enclaves are porphyritic (plagioclase phenocrysts) and are composed of plagioclase, amphibole, biotite, $\mathrm{K}$-feldspar, pyroxene and quartz. The enclaves are low in $\mathrm{SiO}_{2}$ (50-52 wt.\%) and high in $\mathrm{MgO}$ (6-10 wt.\%) and $\mathrm{K}_{2} \mathrm{O}(\sim 4$ wt.\%). They are also characterized by high $\mathrm{Rb}(150-250 \mathrm{ppm})$ and high $\mathrm{Ni}$ (21-165 ppm), but low Zr (113-168 ppm).

Major element composition was also analysed in dioritic rocks from other localities in the Niemcza Zone (Appendix 1): (1) quartz syenite from Piława, composed of amphibole, alkali feldspar, plagioclase and quartz (Puziewicz, 1987), (2) quartz diorite from Kłośnik composed of plagioclase, biotite, amphibole, pyroxene and quartz and (3) syenite from Wilków Wielki composed of alkali feldspar, biotite, amphibole, plagioclase, quartz and apatite. The rock from Wilków Wielki is chemically distinct from other rocks having low $\mathrm{SiO}_{2}$ and $\mathrm{Al}_{2} \mathrm{O}_{3}$ and high $\mathrm{MgO}, \mathrm{CaO}, \mathrm{K}_{2} \mathrm{O}$ ad $\mathrm{P}_{2} \mathrm{O}_{5}$ (Appendix 1).

\section{ZIRCON AGES}

Zircons from both dioritic samples are euhedral and short to normal prismatic (Fig. 3C-F). They show weak oscillatory zoning in charge contrast images. The grains from Przedborowa are larger (approximately $100 \mathrm{~mm}$ or more in the diameter perpendicular to $z$ axis) than the grains from Koźmice (less than $100 \mathrm{~mm}$ in the diameter). Ten zircon grains from Przedborowa and nine grains from Koźmice were analysed (one analysis per grain, Fig. 3C-F, all grains). All ages are Concordia within $\pm 5 \%$, none of the analyses were rejected (Appendix 1). The zircons from Przedborowa yield a single Concordia age of $341.8 \pm 1.9 \mathrm{Ma}$ (Fig. 4A). All nine grains from Koźmice do not yield a Concordia age, as two of the grains (Koz-1, Koz-8) are older with an age of ca. $350 \mathrm{Ma}$ (Appendix 1). The remaining seven grains yield a Concordia age of $335.6 \pm 2.3 \mathrm{Ma}$ (Fig. 4B). Ten grains from Przedborowa and seven grains from Koźmice yield a single Concordia age of $339.2 \pm$ $1.9 \mathrm{Ma}$, but with an MSWD of 3.1.

\section{DISCUSSION}

\section{NIEMCZA MAGMATISM:}

\section{OVER 10 MY OF MAGMA EMPLACEMENT?}

The interpretation of zircon ages requires knowledge of when the zircon crystallised during magma evolution. Dioritic rocks are low in silica and zirconium and, therefore, undersaturated in zircon until late in the crystallisation history (Watson and Harrison, 1983). The inherited component in dioritic zircon is scarcely present and that makes interpretation of zircon ages more straightforward. The temperature of zircon saturation calculated in this study (following zircon saturation thermometer of Watson and Harrison,

A

B
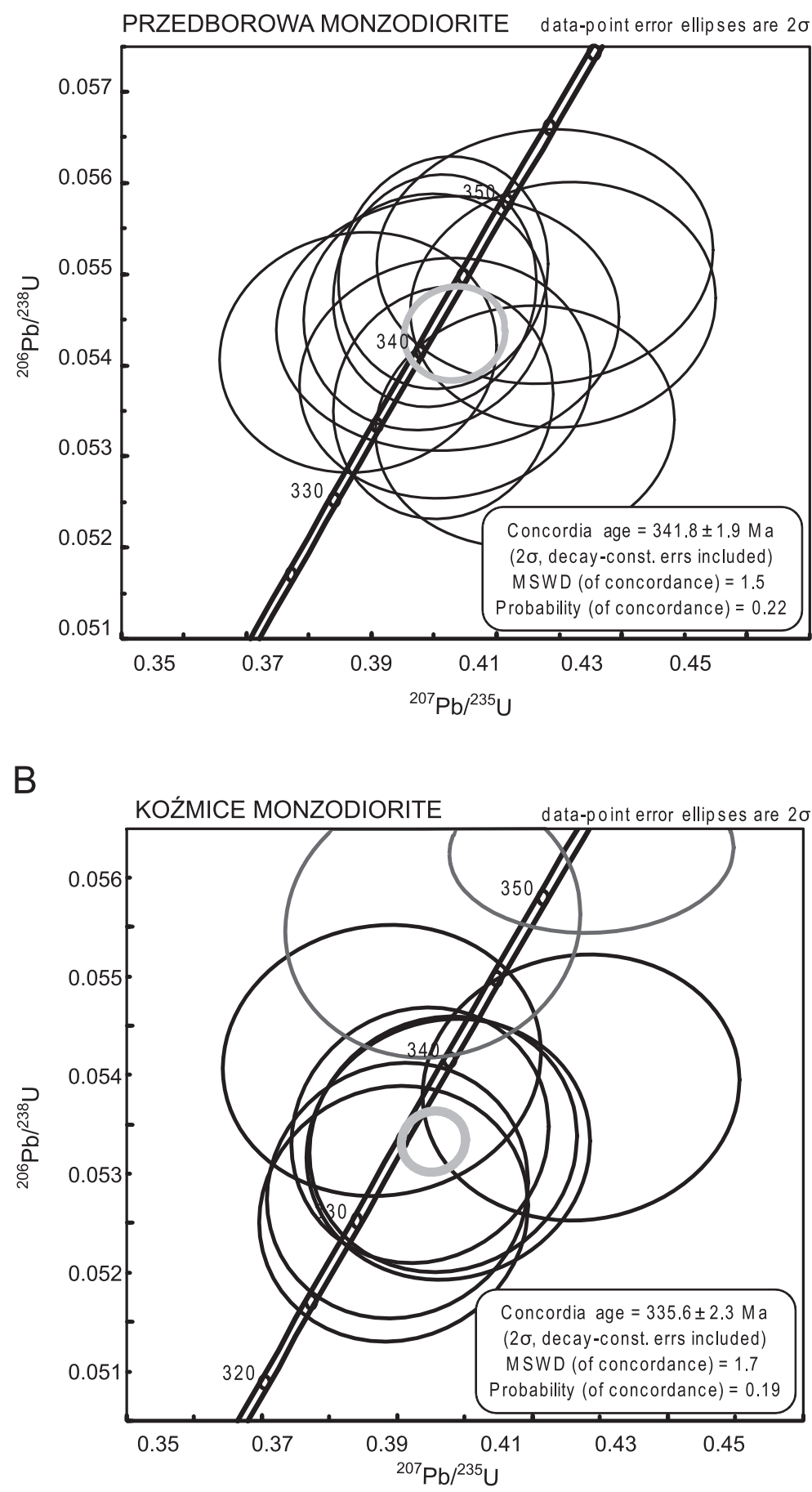

Fig. 4. Conventional concordia diagrams for zircons from Przedborowa (A) and Koźmice (B)

Black circles represent ages accepted for the concordia age (see text for the discussion)

1983) is below $700^{\circ} \mathrm{C}$ for Przedborowa and below $660^{\circ} \mathrm{C}$ for Koźmice, much lower than the typical liquidus and also solidus temperatures for quartz diorite magmas (Pietranik et al., 2009). After approximately $70 \%$ of crystallisation, zircon saturation is around $800^{\circ} \mathrm{C}$ in the studied compositions. The implication is that zircon in monzodioritic magmas crystallises late and its age should be interpreted as the age of the emplacement of 
magma. It is consistent with the structural position of zircon in Koźmice and Przedborowa, which forms euhedral grains enclosed in the rims of mafic minerals (Fig. 3A, B).

The Concordia ages for the Przedborowa and Koźmice monzodiorites are ca. $342 \pm 2$ Ma and $336 \pm 2$ Ma suggesting that the Przedborowa intrusion might be older. However, only seven out of nine zircons from Koźmice yielded a concordia age, whereas two grains are older (ca. $350 \mathrm{Ma}$ ), which makes the age interpretation for Koźmice ambiguous. Therefore, the best constraint on the age of the monzodiorite emplacement is ca. $342 \pm 2$ Ma obtained from zircons from Przedborowa.

Interestingly, the age distribution is similar to that from the Koźmice monzodiorite and was noted by Kryza (2011) for leucogranite from the Gogołów-Jordanów serpentinite massif (dated by U-Pb, SHRIMP). The zircons from the leucogranite also include a main age population around $337 \mathrm{Ma}$ and a single zircon grain with an age around $350 \mathrm{Ma}$. The slight "smearing" of ages along the concordia plot for both the Koźmice monzodiorite and Gogołów-Jordanów leucogranite may suggest that the real age for both intrusions is older and the ages were affected by $\mathrm{Pb}$-loss. However, it would be surprising if both the monzodiorite and leucogranite, magmas with distinct thermal histories and zircon saturation temperatures, were similarly affected by Pb-loss. Also, the Koźmice grains are small and homogenous, similar to grains crystallised in quickly cooled, low Si magmas. They do not show any features typical of hydrothermal alteration (Kusiak et al., 2009) or Pb-loss (Kryza et al., 2012). Alternatively, the 336-337 Ma age could be the age of emplacement for both the Koźmice and Gogołów-Jordanów intrusions and the older
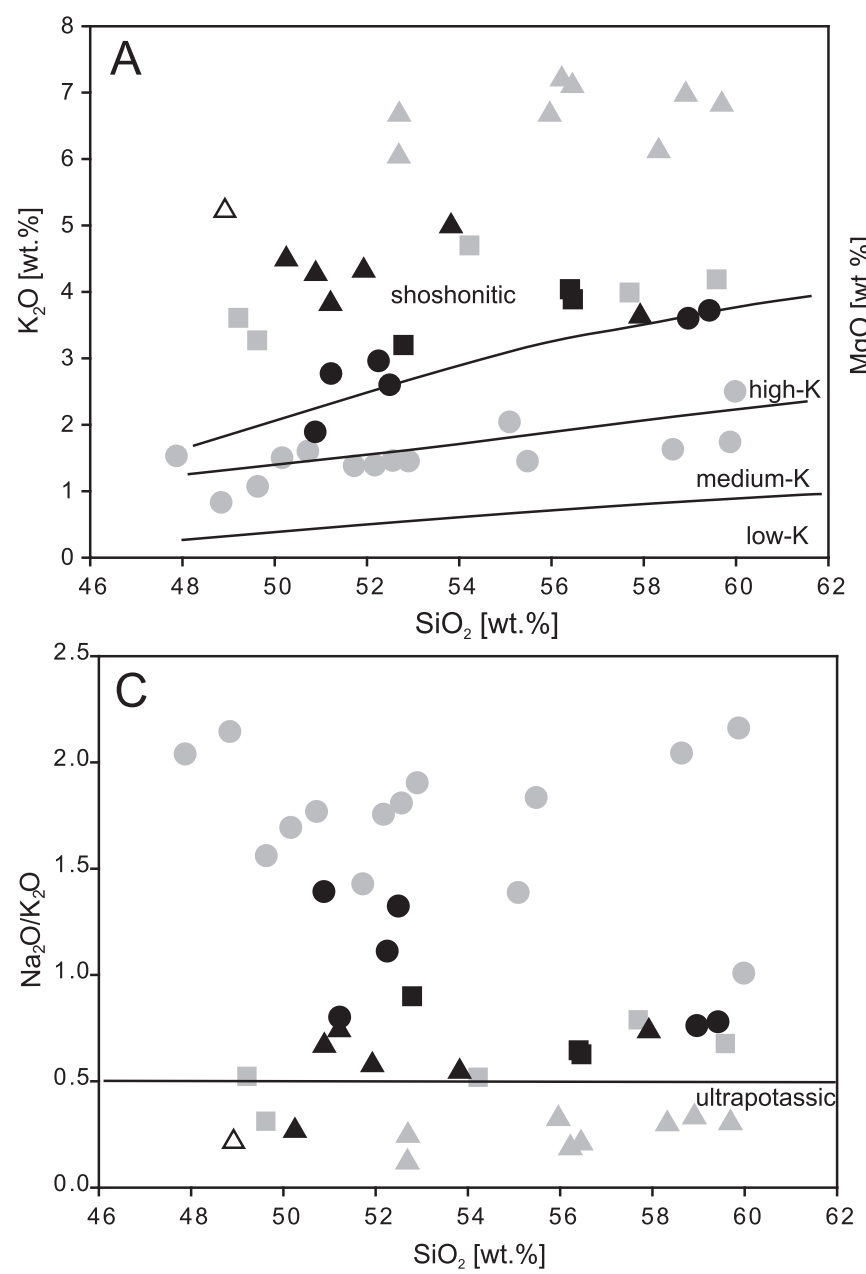

350 Ma zircons are inherited. The older grains from Koźmice have similar colour and morphology to the younger, clustered analyses and similar characteristics of $350 \mathrm{Ma}$ and younger grains were also noted for the Gogołów-Jordanów leucogranite (Kryza, 2011). In this case the inherited signal is real, as might be suggested by the occurrence of similar grains in two localities, the $350 \mathrm{Ma}$ old grains probably come from a pluton, initially emplaced below the level of the Koźmice and Gogołów-Jordanów intrusions emplacement. The injection of new magma at ca. $336 \mathrm{Ma}$ could have disintegrated the older, already solidified rocks. Remelting of this older igneous source could have also produced leucogranitic melts, such as those which intruded the Gogołów-Jordanów massif (Kryza, 2011). Recycling of inherited zircon grains, only a few Ma older than the intrusion age, is observed in other intrusions world-wide (e.g., Coleman et al., 2004).

In this light, the age of ca. 342 Ma obtained for homogeneous zircon population in Przedborowa seems to be a good approximation of the emplacement age for dioritic magmas in the Niemcza Zone, but the second episode of magmatic activity could have taken place several million years later. Also, the magmatism in the area could have started before $350 \mathrm{Ma}$ and could be represented by a hidden pluton.

\section{GEOCHEMISTRY OF THE NIEMCZA ZONE ROCKS: FROM HIGH-K TO ULTRAPOTASSIC MAGMATISM}

The geochemical composition of dioritic rocks from the Niemcza Zone shows that they are mostly shoshonitic (Fig. 5A;

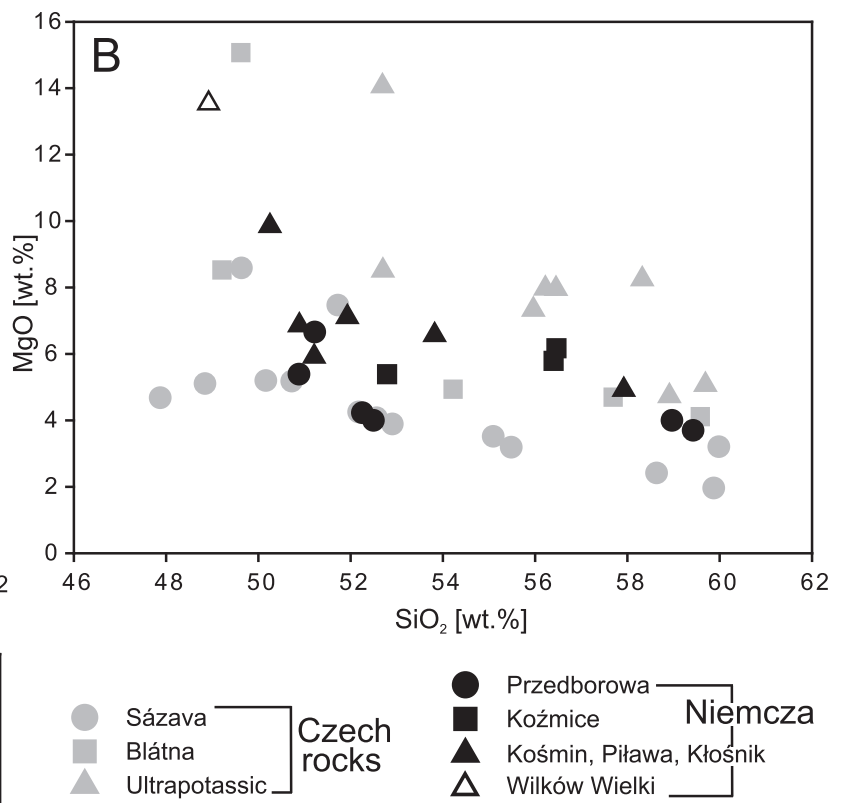

Fig. 5. Major element composition of rocks from the Niemcza Zone compared with other intrusive rocks of similar ages from the Bohemian Massif

Data sources for the Czech rocks: Janoušek et al. (2000, 2004; Kotková et al., 2010; Parat et al., 2010) A - classification after Peccerillo and Taylor (1976) 
Peccerillo and Taylor, 1976), with scarce high-K (Przedborowa) and ultrapotassic rocks (Wilków Wielki and one enclave from Kośmin). Comparing rocks with low $\mathrm{SiO}_{2}$ content (48-53 wt.\%) shows that Przedborowa has generally lower $\mathrm{K}_{2} \mathrm{O}, \mathrm{MgO}, \mathrm{Rb}$ and $\mathrm{Ni}$ from all other diorites in the Niemcza Zone. The implication is that if the age difference between Przedborowa and Koźmice is real it correlates with a change in magma chemistry from high-K to shoshonitic over approximately $5 \mathrm{Ma}$. Interestingly, a similar change was observed in other intrusive rocks from the Bohemian Massif (Janoušek et al., 2000). Magmatic rocks with ages of 375-335 Ma are widespread in the Central Bohemian Massif and they are interpreted as related to the subduction and the subsequent collision of the Saxothuringian plate under the Teplá-Barrandian unit (Schulmann et al., 2009; Žák et al., 2011). Between 354 and ca. $340 \mathrm{Ma}$, the magma chemistry changed from normal high-K calc-alkaline (e.g., Sázava pluton at $354 \pm$ $4 \mathrm{Ma}$; Janoušek et al., 2004) to shoshonitic (e.g., Blatná suite $346 \pm 10$ Ma; Holub, 1997; $346 \pm 2$ Ma; Janoušek et al., 2010 or Klatovy granodiorite $347+3 /-4 \mathrm{Ma}$; Dörr and Zulauf, 2010) and to ultrapotassic (e.g., Třebic pluton, $341.6 \pm 2.8 \mathrm{Ma}$; Kusiak et al., 2010; or Jihlava pluton, $335.1 \pm 0.6 \mathrm{Ma}$; Kotková et al., 2010). This change in geochemistry was observed in both dioritic and granitic rocks and for the dioritic magmas it indicates a change in mantle geochemistry as the mantle evolves from slightly de- pleted at ca. $350 \mathrm{Ma}$ to strongly enriched at ca. $340 \mathrm{Ma}$ (Janoušek et al., 2004; Janoušek and Holoub, 2007). Comparison of geochemical composition between the dioritic rocks from the Niemcza Zone and those from the Central Bohemian Plutonic Complex as well as Třebic and Jihlava plutons (Figs. 5 and 6 ) shows that most of the Niemcza Zone diorites are compositionally similar to the high-K calc-alkaline to shoshonitic rocks from the Central Bohemian Plutonic Complex that intruded at ca. 354-346 Ma (high-K calc-alkaline rocks of the Sázava suite and shoshonitic rocks of the Blatná suite). Normal calc-alkaline rocks also occurring in the Sázava suite were not found in the Niemcza Zone. So far only the dioritic rock from Wilków Wielki and dioritic enclave from Kośmin have geochemical composition similar to that of the ultrapotassic intrusions with intrusion ages around 340-335 Ma. These two rocks were not dated and further age - geochemistry correlations cannot be done.

The general implication is that the dioritic magmatism in the Niemcza Zone records a change in the chemistry of intrusive rocks similar to that observed in the Central Bohemian Plutonic Complex from 354 to $346 \mathrm{Ma}$ (high-K calc-alkaline to shoshonitic), but the change in the Niemcza Zone occurred probably between 342 and $336 \mathrm{Ma}$ ago, ca. $10 \mathrm{Ma}$ later. The geochemical evolution of magmas in the Central Bohemian Plutonic Complex is related to the subduction of Saxothuringian domain under the
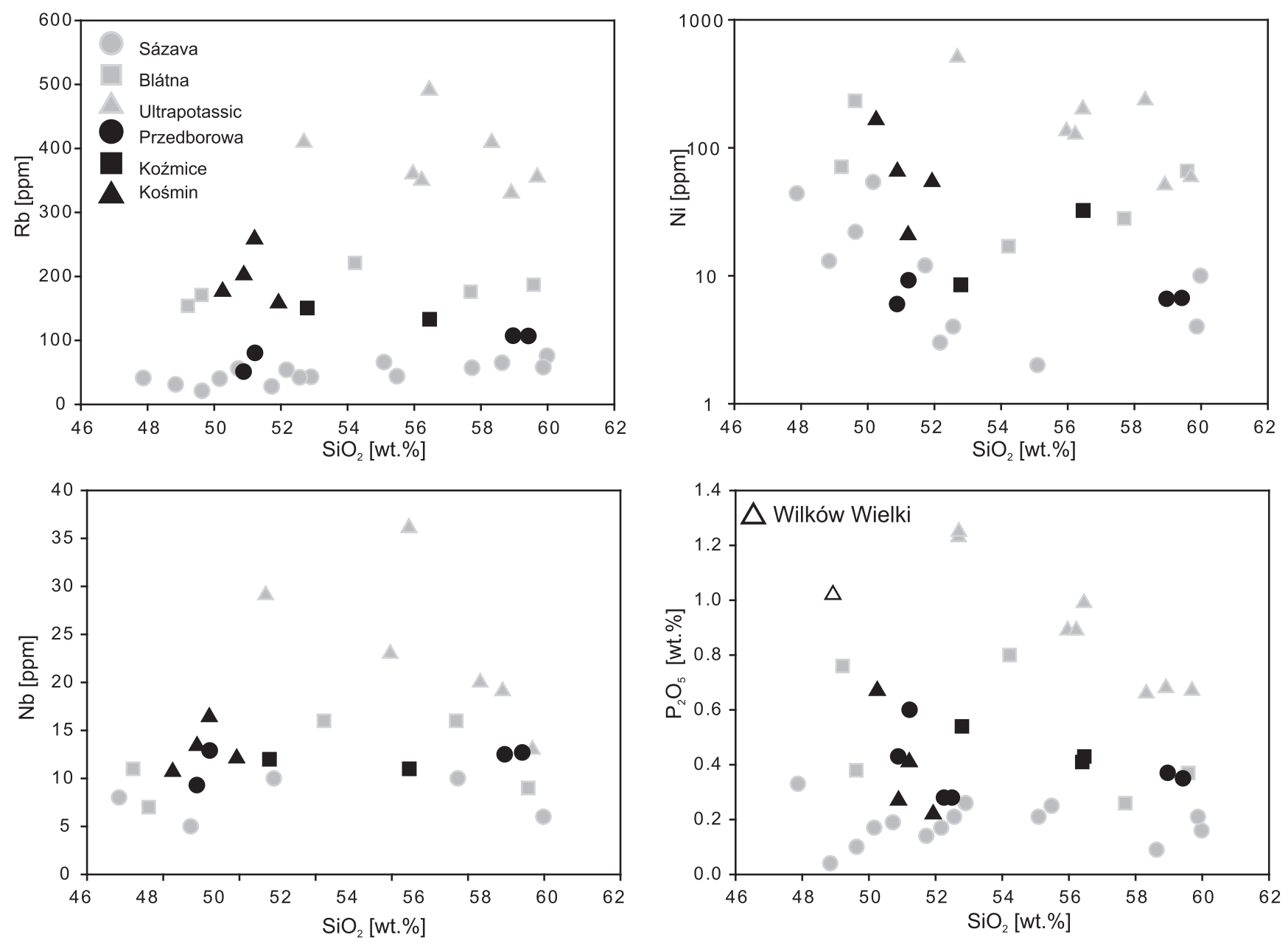

Fig. 6. Trace element composition of rocks from the Niemcza Zone compared with other intrusive rocks of similar ages from the Bohemian Massif 
Teplá-Barrandian microplate and change in the mantle chemistry with the final emplacement of ultrapotassic rocks derived from the underthrusted Saxothuringian continental crust and strongly enriched mantle (Janoušek and Holub, 2007; Žák et al., 2011). By correlation, a similar process could have taken place in the Sudetes, also in response to the collision between two domains, probably Saxothuringian and Moldanubian. However, such a conclusion should be supported by further precise dating coupled with geochemical and petrological analyses of dioritic rocks from Wilków Wielki and enclaves from Kośmin as well as other localities of diorities such as Kłośnik and Niemcza. Also, further comparison of magmatic and subsolidus fabrics in the intrusive rocks of the Niemcza Zone (so far only done for the Koźmice granodiorite; Puziewicz, 1992) with well-documented fabrics observed in the Central Bohemian Plutonic Complex (Žák et al., 2012) could provide additional information on correlations between tectonic regimes in the two areas. Precise dating of the granulites from the Orlica-Śnieżnik Massif (Anczkiewicz et al., 2007; Walczak, 2011) should show if they are temporally related to the ultrapotassic magmatism in the Niemcza Zone similarly to the relations observed for the Central Bohemian Plutonic Complex (Janoušek and Holub, 2007).

\section{CONCLUSIONS}

The monzodioritic rocks from the Niemcza Zone record a change in geochemistry from high- $\mathrm{K}$ to shoshonitic magmas over less than $10 \mathrm{Ma}$. Zircon yields magma emplacement ages of $341.8 \pm 1.9 \mathrm{Ma}$ for Przedborowa (high-K) and $335.6 \pm 2.3 \mathrm{Ma}$ for Koźmice (shoshonitic). The difference in chemical composi- tion of Przedborowa and Koźmice rocks reflects the increasing enrichment of the underlying mantle from ca. 342 to ca. $336 \mathrm{Ma}$. Similar evolution of mantle composition is recorded in rocks from the Central Bohemian Plutonic Complex from ca. 354 to ca. $347 \mathrm{Ma}$, therefore over a similar time-span as that suggested for the Niemcza Zone. Chemical and temporal correlations between the two areas suggest that (1) similar geotectonic setting developed diachronously in different parts of the Bohemian Massif and (2) the time-span of ca. 6-7 My is required to evolve from high- $\mathrm{K}$ to shoshonitic magmatism. The ultrapotassic rocks, such as those which affected the Czech part of the Bohemian Massif at 340-335 Ma, were not dated in this study, but syenites from Wilków Wielki are potential candidates to constrain timing of the ultrapotassic magmatism in the Sudetes.

Acknowledgements. J. Puziewicz and J. Leichmann are thanked for the field trip during which samples were collected and for interesting discussion that started work on this project. J. Puziewicz is thanked for helpful comments on the earlier version of this manuscript. K. Dymna is thanked for zircon separation. Master thesis of J. Gruszczyńska and A. Winiecka helped to locate representative samples of the Kośmin enclaves. M. Kusiak, S. Mazur and J. Žák are thanked for their helpful comments and improvement of this manuscript. AP acknowledges grant no. N N307 105235 by the Polish Ministry of Science and Higher Education. JK acknowledges the Project "Development of the potential and educational offer of the University of Wrockaw - the chance to enhance the competitiveness of the University" co-financed by the European Union under the European Social Fund.

\section{REFERENCES}

Aleksandrowski P., Kryza R., Mazur S., Żaba J. (1997) Kinematic data on major Variscan strike-slip faults and shear zones in the Polish Sudetes, northeast Bohemian Massif. Geological Magazine, 134 (5): 727-739.

Anczkiewicz R., Mazur S., Szczepański J., Storey C., Crowley Q., Villa I.M., Thirlwall M., Jeffries T.E. (2007) Lu-Hf geochronology and trace element distribution in garnet: implications for uplift and exhumation of ultra-high pressure granulites in the Sudetes, SW Poland. Lithos, 95: 363-380.

Badura J., Dziemiańczuk E. (1981) Szczegółowa mapa geologiczna Sudetów 1:25 000, ark. Ząbkowice Śląskie. Wydawnictwa Geologiczne, Warszawa.

Coleman D.S., Gray W., Glazner A.F. (2004) Rethinking the emplacement and evolution of zoned plutons: geochronologic evidence for incremental assembly of the Tuolumne Intrusive Suite, California. Geology, 32 (5): 433-436.

Cwojdziński S., Walczak-Augustyniak M. (1983) Szczegółowa mapa geologiczna Sudetów 1:25 000, ark. Niemcza. Wydawnictwa Geologiczne, Warszawa.

Cymerman Z., Walczak-Augustyniak M. (1986) Szczegółowa mapa geologiczna Sudetów 1:25 000, ark. Dzierżoniów. Wydawnictwa Geologiczne, Warszawa.

Dörr W., Zulauf G. (2010) Elevator tectonics and orogenic collapse of a Tibetan-style plateau in the European Variscides: the role of the Bohemian shear zone. International Journal of Earth Sciences, 99: 299-325.

Dörr W., Żelaźniewicz A., Bylina P., Schastok J., Franke W., Haack U., Kulicki C. (2006) Tournaisian age of granitoids from the Odra fault zone (southwestern Poland): equivalent of the
Mid-German crystalline high. International Journal of Earth Sciences, 95: 341-349.

Dudek K., Wojtowicz A., Korzeniowska A. (2000) Ar-Ar dating of hornblende from pegmatite in quartz monzodiorite from Przedborowa (Lower Silesia, Poland) - preliminary results. Mineralogia Polonica, 31 (2): 75-83.

Dziedzicowa H. (1963) So-called syenites of the Niemcza Zone (Lower Silesia). Archiwum Mineralogiczne, 24 (2): 5-109.

Holub F.V. (1997) Ultrapotassic plutonic rocks of the durbachite series in the Bohemian Massif: petrology, geochemistry, and petrogenetic interpretation. Journal of Geological Sciences - Economic Geology, Mineralogy, 31: 5-26.

Janoušek V., Gerdes A. (2003) Timing the magmatic activity within the Central Bohemian Pluton, Czech Republic: conventional $\mathrm{U}-\mathrm{Pb}$ ages for the Sázava and Tábor intrusions and their geotectonic significance. Journal of the Czech Geological Society, 48 (1-2): 70-71.

Janoušek V., Holub F.V. (2007) The casual link between HP-HT metamorphism and ultrapotassic magmatism in collisional orogens: case study from the Moldanubian Zone of the Bohemian Massif. Proceedings of the Geologists' Association, 118: $1-12$.

Janoušek V., Bowes D.R., Rogers G., Farrow C.M., Jelinek E. (2000) Modelling diverse processes in the petrogenesis of a composite batholith: the Central Bohemian Pluton, Central European Hercynides. Journal of Petrology, 41: 511-543.

Janoušek V., Braithwaite C.J.R., Bowes D.R., Gerdes A. (2004) Magma mixing in the genesis of Hercynian calc-alkaline granitoids: an integrated petrographic and geochemical study of 
the Sázava intrusion, Central Bohemian Pluton, Czech Republic. Lithos, 78: 67-99.

Janoušek V., Wiegand B., Žák J. (2010) Dating the onset of Variscan crustal exhumation in the core of the Bohemian Massif: new $\mathrm{U}-\mathrm{Pb}$ single zircon ages from the high-K calc-alkaline granodiorites of the Blatná suite, Central Bohemian Pluton. Journal of the Geological Society, 167: 347-360.

Kotková J., Schaltegger U., Leichmann J. (2010) Two types of ultrapotassic plutonic rocks in the Bohemian Massif - coeval intrusions at different crustal levels. Lithos, 115: 163-176.

Kryza R. (2011) Early Carboniferous ( $337 \mathrm{Ma}$ ) granite intrusion in Devonian ( $400 \mathrm{Ma})$ ophiolite of the Central-European Variscides. Geological Quarterly, 55 (3): 213-222.

Kryza R., Pin C. (2010) The Central-Sudetic ophiolites (SW Poland): petrogenetic issues, geochronology and palaeotectonic implications. Gondwana Research, 17 (2-3): 292-305.

Kryza R., Crowley Q.G., Larionov A., Pin C., Oberc-Dziedzic T., Mochnacka K. (2012) Chemical abrasion applied to SHRIMP zircon geochronology: An example from the Variscan Karkonosze Granite (Sudetes, SW Poland). Gondwana Research, 21: 757-767.

Kusiak M.A., Dunkley D.J., Słaby E., Martin H., Budzyń B. (2009) Sensitive high resolution ion microprobe analysis of zircon reequilibrated by late magmatic fluids in a hybridized pluton. Geology, 37 (12): 1063-1066.

Kusiak M.A., Dunkley D.J., Suzuki K., Kachlik V., Kedzior A., Lekki J., Opluštil S. (2010) Chemical (non-isotopic) and isotopic dating of Phanerozoic zircon - a case study of durbachite from the Třebíč Pluton, Bohemian Massif. Gondwana Research, 17: 153-161.

Leichmann J., Gawęda A. (2002) Niemcza Zone granitoids durbachites in Sudetes. Geolines, 14: 60.

Lorenc M.W. (1998) Badania izotopowe metoda Rb/Sr skał intruzywnych strefy Niemczy. Archiwum Mineralogiczne, 51: 153-164.

Lorenc M., Kennan P. (2007) Intrusive rocks from the Niemcza zone (Lower Silesia, Poland) in the light of petrologic and Rb-Sr isotope studies. Archiwum Mineralogiczne Monograph, 1: 253-259.

Ludwig K.R. (1999) Using Isoplot/Ex Version 2.01: a geochronological toolkit for Microsoft Excel. Berkeley Geochronology Center Special Publications, 1a.

Mazur S., Puziewicz J. (1995) Mylonites of the Niemcza zone. Annales Societatis Geologorum Poloniae, 64: 23-52.

Mazur S., Aleksandrowski P., Kryza R., Oberc-Dziedzic T. (2006) The Variscan orogen in Poland. Geological Quarterly, 50 (1): $89-118$

Mazur S., Aleksandrowski P., Turniak K., Awdankiewicz M. (2007) Geology, tectonic evolution and Late Palaeozoic magmatism of Sudetes - an overview. Archiwum Mineralogiczne Monograph, 1: 59-87.

Nebel O., Mezger K., Scherer E.E. (2011) Evaluation of the ${ }^{87} \mathrm{Rb}$ decay constant by age comparison against the U-Pb system. Earth and Planetary Science Letters, 301: 1-8.

Oberc-Dziedzic T., Kryza R. (2012) Late stage Variscan magmatism in the Strzelin Massif (SW Poland): SHRIMP zircon ages of tonalite and Bt-Ms granite of the Gesiniec intrusion. Geological Quarterly, 56 (2): 225-236.

Oberc-Dziedzic T., Kryza R., Białek J. (2010) Variscan multistage granitoid magmatism in Brunovistulicum: petrological and SHRIMP U-Pb zircon geochronological evidence from the southern part of the Strzelin Massif, SW Poland. Geological Quarterly, 54 (4): 301-324.

Oliver G.J.H., Corfu F., Krough T.E. (1993) U-Pb ages from SW Poland: evidence for a Caledonian suture zone between Baltica and Gondwana. Journal of Geological Society of London, 150: 355-369.

Parat F., Holtz F., René M., Almeev R. (2010) Experimental constraints on ultrapotassic magmatism from the Bohemian Massif (durbachite series, Czech Republic). Contributions to Mineralogy and Petrology, 159: 331-347.

Peccerillo A.S.R., Taylor S.K. (1976) Geochemistry of Eocene calc-alkaline volcanic rocks from the Kastamoru area, northern Turkey. Contributions to Mineralogy and Petrology, 58: 63-81.

Pietranik A., Holtz F., Koepke J., Puziewicz J. (2009) Crystallization of quartz dioritic magmas at 2 and 1 kbar: experimental results. Mineralogy and Petrology, 97 (1-2): 1-21.

Puziewicz J. (1987) Petrografia, geneza i autometamorfizm syenitu z Piławy Górnej i jego pegmatytów. Archiwum Mineralogiczne, 43: $5-22$.

Puziewicz J. (1988) Plagioclase - pyroxene - biotite rock from the Koźmice quarry, Niemcza zone (Sudetes, SW Poland): the first occurrence of vaugnerite in Polish Sudetes. Mineralogia Polonica, 19 (2): 59-66.

Puziewicz J. (1990) Amfibole oraz towarzyszące im minerały żelaza i magnezu z monzodiorytu kwarcowego z Przedborowej (Dolny Śląsk). Archiwum Mineralogiczne, 45 (1-2): 61-78.

Puziewicz J. (1992) Geneza granodiorytu z Koźmic (strefa Niemczy, Dolny Śląsk). Archiwum Mineralogiczne, 47 (2): 95-146.

Puziewicz J., Oberc-Dziedzic T. (1995) Wiek i pochodzenie granitoidów bloku przedsudeckiego. Przewodnik LXVI Zjazdu PTG: 273-284.

Puziewicz J., Radkowska M. (1990) Formy kryształów cyrkonu z granitoidów i syenitoidów/diorytoidów strefy Niemczy (Dolny Śląsk) jako wskaźnik petrogenetyczny. Archiwum Mineralogiczne, 46 (1-2): 123-143.

Schulmann K., Konopásek J., Janoušek V., Lexa O., Lardeaux J.-M., Edel J.-B., Štípská P., Ulrich S. (2009) An Andean type Palaeozoic convergence in the Bohemian Massif. Comptes Rendus Geoscience, 341: 266-286.

Sláma J., Košler J., Condon D.J., Crowley J.L., Gerdes A., Hanchar J.M., Horstwood M.S.A., Morris G.A., Nasdala L., Norberg N., Schaltegger U., Schöne B., Tubrett M.N., Whitehouse M.J. (2008) Plešovice zircon - a new natural reference material for U-Pb and $\mathrm{Hf}$ isotopic microanalysis. Chemical Geology, 249: 1-35.

Trepka S., Gawroński O. (1957) Szczegółowa mapa geologiczna Sudetów 1:25 000, ark. Ostroszowice. Wydawnictwa Geologiczne, Warszawa.

Turniak K., Tichomirowa M., Bombach K. (2005) Zircon Pb-evaporation ages of granitoids from the Strzegom-Sobótka Massif (SW Poland). Mineralogical Society Poland - Special Papers, 25: $241-245$

Walczak K. (2011) Interpretacja datowań Sm-Nd i Lu-Hf granatów w skałach wysokociśnieniowych i wysokotemperaturowych w świetle badań dystrybucji pierwiastków śladowych. Unpublished $\mathrm{PhD}$ thesis, University of Wrocław.

Watson E.B., Harrison M. (1983) Zircon saturation revisited: temperature and composition effects in a variety of crustal magma types. Earth and Planetary Science Letters, 64: 295-304.

Wenzel T., Mertz D.F., Oberhänsli R., Becker T. (1997) Age, geodynamic setting and mantle enrichment processes of a K-rich intrusion from the Meissen massif (northern Bohemian massif) and implications for related occurrences from the midEuropean Hercynian. Geologische Rundschau, 86: 556-570.

Wiedenbeck M., Alle P., Corfu F., Griffin W.L., Meier M., Oberli F., von Quadt A., Roddick J.C., Speigel W. (1995) Three natural zircon standards for U-Th-Pb, Lu-Hf, trace-element and REE analyses. Geostandards Newsletter, 19: 1-23.

Žák J., Kratinová Z., Trubač J., Janoušěk V., Sláma J., Mrlina J. (2011) Structure, emplacement, and tectonic setting of Late Devonian granitoid granitoid plutons in the Teplá-Barrandian unit, Bohemian Massif. International Journal of Earth Sciences, 100: 1477-1495.

Žák J., Verner K., Holub F., Kabele P., Chlupáčová M., Halodová P. (2012) Magmatic to solid state fabrics in syntectonic granitoids recording early Carboniferous orogenic collapse in the Bohemian Massif. Journal of Structural Geology, 36: 27-42. 